\title{
PERCEPTION OF LEADERSHIP IN SLOVAKIA
}

\section{Lukáš SMEREK}

Department of Corporate Economics and Management, Faculty of Economics, Matej

Bel University in Banská Bystrica, Slovakia

\section{Monika ŠURINČÍKOVÁ}

Department of Corporate Economics and Management, Faculty of Economics, Matej

Bel University in Banská Bystrica, Slovakia

Received: 03. November 2020, Reviewed:14. December 2020, Accepted:30. December 2020

\begin{abstract}
The article is focused on leadership in Slovak companies. Its aim is to analyse the perception of leadership by employees of Slovak companies and to identify the characteristics, abilities and skills that a leader should have. We carried out our own research in the form of a questionnaire survey on a sample of 508 respondents working in Slovak companies. The primary intention was to determine whether employees considered their direct supervisor to be a leader, to identify the qualities that employees look for in a leader. The most common positive qualities of a leader are generally considered to be receptivity, empathy, representativeness, helpfulness, fairness, directness, responsibility, intelligence, foresight, self-confidence, dexterity, communicativeness, decency and honesty towards subordinates and clients. On the contrary, the most common reasons why bosses were not considered leaders are the inability to work and communicate with people, the absence of natural authority and respect, disorganization of the workplace, lack of education, incompetence, absence of information about the company and the work of individual subordinates. Applying the Chi-Square Test of Independence with Cramer's V, it has been found that there is a strong correlation between the perception of a superior as a leader and the thoughts a bout changing a job.
\end{abstract}

Keywords: leadership, management, leader, boss, Slovak companies

JEL Classification: M12, M14, O15

\section{Introduction}

In any company, employees are an indispensable part who can significantly increase competitiveness. However, this is only achieved if the work of employees is managed and coordinated towards set goals and at the same time if they are properly lead and motivated to work willingly and enthusiastically. A certain management system is very important for the efficient functioning of all economic entities 
(companies) regardless of the number of employees. Without the existence of this system, "everyone would do everything, but no one would do anything." Chaos would prevail, in which no one would know their powers, duties and responsibilities. Management levels and hierarchy and subordination bring order to the company. This creates superior positions with certain powers over other employees. However, it is also important how power thus entrusted is approached, whether the bosses can only manage the company or are able to lead it.

For the effective functioning of any company there must be a certain organizational structure, which depends mainly on the number of employees. Whether it is a small company with a few employees or a large manufacturing company with many departments and divisions, individual employees need to be familiar with their roles and responsibilities; the need to know who their superior is, who has to carry out the orders and who they report to. It does not matter whether they are called a supervisor, manager, superior or boss, they are still people with whom subordinates come into contact on a daily basis and therefore they depend a lot on their superiors.

Thomasová (2000) claims that enterprises, especially medium and large companies, cannot be managed as unstructured units; they must be divided into smaller management units. The author defines organizational structure as a set of elements (departments), as the creation of different types and numbers of intra-organizational units, while the ultimate goal of creating departments (plants, departments, divisions, branches, factories, etc.) is to support more effective management of the company as a whole and thus ensuring the effective fulfilment of its objectives stated in advance. However, the relationships and links between these departments are also very important for achieving goals. There are three types of relationships - vertical relationships (relationships of superiority and subordination, orders proceed from above from managers and superiors to subordinate units), horizontal relationships (relationships between individual units that are not based on the principle of superiority and subordination) and diagonal relationships (forming across different departments, which are mostly of informal nature).

The division of labour and objective needs lead to the fact that people, whom we can generally call managers, are at the head of working groups, organizational units but also at the head of entire companies. Whether these individuals have been formally elected and appointed or informally recognized, their role is important because they are responsible for the group as a whole and for coordinating the activities of its members in achieving common goals (Hrmo, 1988 In Gozora, 2005).

\section{Theoretical background}

As stated by Sutton (2010), bosses are important because most employees have a boss, they are bosses themselves or they have both roles. He adds that bosses are important for every employee who is in the organizational structure (in the company hierarchy) below them. They are at work together every day. Bosses lead, coordinate and evaluate. The employees are in close contact with their bosses' personality, their weaknesses, virtues but also whims. Employees almost never leave companies, but they leave bad bosses. This is because it does not matter whether companies are rated as good or bad or a great or poor working environment, the satisfaction, effort and performance of employees is much more influenced by their immediate superiors.

With the position of a boss there comes certain authority, the power to decide in the interests of a company, to make decisions regarding on the tasks of subordinates 
and their overall coordination. However, authority does not make bosses leaders. They simply remain only bosses if they possess exclusively authority. Bosses tell their subordinates to meet tasks and goals, while leadership is different in in a way that subordinates want to meet set goals. This way, we distinguish between assigned leadership, which is based on the formal position of authority, and emergent leadership, which manifests itself by influencing others (Steigauf, 2011).

As mentioned above, a certain position does not automatically guarantee leadership. Bosses do not automatically become leaders immediately. The term leader is often confused with the notion of manager, respectively. Each manager is automatically considered a leader. However, this is a big and serious mistake. Mintzberg (1989, In Seková et al., 2013) formulated an approach to the work of a manager based on roles, which he divided into interpersonal (company representative, company leader, connecting link), information (information recipient, disseminator, speaker) and decision-making roles (entrepreneur, problem solver, resource allocator, negotiator). Thus, it can be said that managers are people whose primary activities are managerial functions through which they act on the objects of management. They are people who plan, organize, manage and control human, financial and information resources in order to achieve set goals. Every manager can be a leader, but not everyone is one. First, we need to understand the basic tasks and characteristics of a manager's work in order to better perceive the difference between a manager and a leader. Blažek (2014) explains this difference simply. According to the author, the concept of a leader is related to the role, and the concept of a manager is related to a job position. Individuals become leaders informally (naturally) when they gain followers who respect their influence. When they lose followers, they cease to be leaders. People become managers formally; they placed in a certain position, which gives them the power to manage resources and thus their subordinates. When they lose their position, they stop being a manager. These differences are shown in Table 1.

Table 1 Differences between leadership and management

\begin{tabular}{|l|c|c|}
\hline Category & Leadership & Management \\
\hline \multirow{4}{*}{ Thinking process } & Focus on people & Focus on things \\
\hline \multirow{4}{*}{ Setting goals } & Looking outside & Looking inside \\
\cline { 2 - 3 } & Formulate a vision & Execute plans \\
\cline { 2 - 3 } & Creating the future & Improve presence \\
\hline \multirow{4}{*}{ Relations with employees } & Seeing the forest & Seeing the trees \\
\cline { 2 - 3 } & Authorize & Control \\
\cline { 2 - 3 } & Colleagues & Subordination \\
\hline \multirow{5}{*}{ Operations } & Trust and development & Management and \\
& Do the right things & Do things right \\
\hline \multirow{5}{*}{ Guidance } & Make a change & Manage change \\
\cline { 2 - 4 } & Serve to subordinates & Serve to superiors \\
\cline { 2 - 3 } & Use influence & Use authority \\
\hline
\end{tabular}




\begin{tabular}{|l|c|c|}
\hline \multirow{7}{*}{ Activities } & Change solving & $\begin{array}{c}\text { Managing the complexity of } \\
\text { the organization }\end{array}$ \\
\cline { 2 - 3 } & $\begin{array}{c}\text { Developing the vision and } \\
\text { determining the direction of } \\
\text { the company }\end{array}$ & Planning and budgeting \\
\cline { 2 - 3 } & $\begin{array}{c}\text { Strategy formulation } \\
\text { Alignment of stakeholders } \\
\text { with the vision of the } \\
\text { company }\end{array}$ & $\begin{array}{c}\text { Strategy implementation } \\
\text { Organizing and staffing for } \\
\text { the content of the strategy }\end{array}$ \\
\cline { 2 - 4 } & $\begin{array}{c}\text { Employee motivation and } \\
\text { inspiration }\end{array}$ & $\begin{array}{c}\text { Behaviour control and } \\
\text { problem solving to ensure the } \\
\text { content of the strategy }\end{array}$ \\
\cline { 2 - 4 } & $\begin{array}{c}\text { Recognition and reward of } \\
\text { success }\end{array}$ & $\begin{array}{c}\text { Rewarding success and } \\
\text { punishing failure }\end{array}$ \\
\hline
\end{tabular}

Source: Lunenburg (2011), Henry (2011, In Theodoulides, 2018)

The difference between a manager and a leader can also be expressed by explaining the categories of formal and informal leadership, which are based on the recognition of authority and power. Managers, as representatives of formal management, have a legitimate power (right, authority) that stems from their position. This power serves to influence others in order to achieve the official objectives of undertakings. A leader, as a representative of informal leadership, uses informal power (his ability) to influence informal goals (Kreitner, 1989, In Sedlák, Líšková, 2015). According to the Drucker (1996) there may be "born leaders," but there surely are far too few to depend on them. Leadership must be learned and can be learned. Goleman (2011) explains what the difference between an excellent leader and a good one is. It's not higher IQ or technical skills or anything like that. He says it's emotional intelligence - a group of five abilities that allow a great leader to maximize the performance of himself and his followers. This includes self-awareness, which means knowing your emotions, strengths and weaknesses, motivation, values, attitudes, goals and their impact on others. Also self-monitoring, in which disturbing impulses and moods are controlled or eliminated. The others are motivation and empathy, which helps us to understand and take into account the feelings and emotions of others. Last but not least, it includes social skills, important in building relationships and creating social networks with others.

Leadership styles vary from person to person and it also depends upon situational need (Bass \& Bass, 2009). Leaders and their leadership styles are one of the mostly studied topics of recent history. There are three traditional leadership theories that have been developed over a period of time - trait theory, behavioral theory and contingency theory. Transformational leadership, transactional leadership, culture based leadership, charismatic leadership, visionary leadership can be considered as modern leadership styles (Harris, et al., 2007). Each theory illustrates some distinct dimensions of leadership and each theory explains the leader and follower relation in different ways (Rasool et al., 2015).

Based on the above definitions the concept of leadership is used in two ways: as management defining the function appointed by the formal status, or as leadership when talking about the activity of the recognised person, the leader, in the group. Leaders have all the characteristics of a supervisor. A leader is a person who is followed by others, who has the ability to arouse confidence, inspire others, 
convince them of the correctness of his or her direction, even if the environment does not always have the same opinion. Managers who can lead and have this unique ability to engage people to follow them become leaders. Thanks to their leadership potential, excellent companies are different from good and average ones. It can be said that leaders are persons responsible for the development of the company and its employees, entrepreneurs, energetic and action-oriented, constantly looking for new opportunities to realize them with the people who follow them. The topic of leadership has been in the focus for a long time. Today's organizations need effective leaders who understand the complexities of the rapidly changing global environment. If the task is highly structured and the leader has good relationship with the employees, effectiveness will be high on the part of the employees (Nanjundeswaraswamy, Swamy, 2014). The current situation is no exception. On the contrary, with social, economic, and health systems on the verge of collapsing, it is impossible to know what the new world will look like, but its shape will depend on the decisions leaders are making now (Dirani et al., 2020).

\section{Material and methods}

The aim of the paper is to analyse the perception of leadership by employees of Slovak companies and to identify the characteristics, abilities and skills that a leader should have. To fulfil the aim, 4 research questions were formulated as follows:

RQ1: Do Slovak employees consider their superiors to be leaders?

RQ2: What do Slovak employees consider to be a manifestation of leadership in their superiors?

RQ3: What do Slovak employees consider to be a manifestation of weak leadership in their superiors?

RQ4: Can the perception of leadership affect employee turnover?

We carried out an analysis of the current state of leadership perception using a questionnaire survey. Its aim was to find out how the employees of Slovak companies perceive leadership, whether they consider their bosses to be leaders and what impact it has on their satisfaction and thoughts about leaving their jobs. This questionnaire survey was designed for people older than 18, who work in the Slovak Republic and who have a direct superior. We do not state the exact positions of the respondents, but it is possible that they also have superior employees and/or subordinates. The questionnaire was distributed using Google forms, distribution on social networks, direct contact and the use of word of mouth. Therefore, the return rate cannot be clearly determined. The questionnaire was filled in by 508 respondents. The structure of the research sample is shown in Table 2. 
Table 2 Characteristics of the research sample

\begin{tabular}{|c|c|c|c|c|c|c|c|c|}
\hline \multirow{2}{*}{ Sex } & \multicolumn{4}{|c|}{ Male } & \multicolumn{4}{|c|}{ Female } \\
\hline & \multicolumn{4}{|c|}{$52.56 \%$} & \multicolumn{4}{|c|}{$47.44 \%$} \\
\hline \multirow{2}{*}{ Age } & $18-24$ & \multicolumn{2}{|c|}{$25-34$} & \multicolumn{2}{|c|}{$35-44$} & \multicolumn{2}{|c|}{$45-54$} & $55+$ \\
\hline & $12.80 \%$ & $21.26 \%$ & $27.56 \%$ & $24.21 \%$ & $14.17 \%$ & & & \\
\hline \multirow{2}{*}{ Region* } & BA & TT & NR & $\mathrm{TN}$ & $\mathrm{ZA}$ & BB & KE & PO \\
\hline & $17.13 \%$ & $12.40 \%$ & $12.20 \%$ & $10.63 \%$ & $19.88 \%$ & $15.55 \%$ & $5.71 \%$ & $6.50 \%$ \\
\hline \multirow{2}{*}{ Industry } & \multicolumn{4}{|c|}{ Production } & \multicolumn{4}{|c|}{ Non-production } \\
\hline & \multicolumn{4}{|c|}{$39.17 \%$} & \multicolumn{4}{|c|}{$60.83 \%$} \\
\hline \multirow{2}{*}{ Sector } & \multicolumn{4}{|c|}{ Private } & \multicolumn{4}{|c|}{ Public } \\
\hline & \multicolumn{4}{|c|}{$75.79 \%$} & \multicolumn{4}{|c|}{$24.21 \%$} \\
\hline \multirow{2}{*}{ Employment } & \multicolumn{4}{|c|}{ Full-time } & \multicolumn{4}{|c|}{ Part-time } \\
\hline & \multicolumn{4}{|c|}{$83.07 \%$} & \multicolumn{4}{|c|}{$16.93 \%$} \\
\hline
\end{tabular}

Source: own processing

$B A=$ Bratislava,$T T=$ Trnava,$N R=$ Nitra,$T N=$ Trenčín, $Z A=$ Žilina, $B B=$ Banská Bystrica, $K E=$ Košice, $P O=$ Prešov

We verified the representativeness of the sample using the One Sample ChiSquare Test in the SPSS software. We chose the gender and age of the respondents as the tested characteristics. We obtained data on the basic set from 2020 from the website of the Statistical Office of the Slovak Republic. The results of the representativeness test are shown in Table 3.

Table 3 Representativeness of the research sample

\begin{tabular}{|l|c|c|c|c|c|}
\hline Sex & Observed N & Expected N & Residual & Test statistics & Sex \\
\hline Male & 267 & 278.4 & -11.4 & Chi-Square & $1.030 \mathrm{a}$ \\
Female & 241 & 229.6 & 11.4 & $\mathrm{df}$ & 1 \\
Total & 508 & & & Asymp. Sig. & 0.310 \\
\hline Age & Observed N & Expected N & Residual & Test statistics & Age \\
\hline $18-24$ & 65 & 25.3 & 39.7 & Chi-Square & $67.804 \mathrm{~b}$ \\
$25-34$ & 108 & 116.8 & -8.8 & df & 4 \\
$35-44$ & 140 & 146.5 & -6.5 & Asymp. Sig. & 0.000 \\
$45-54$ & 123 & 127.3 & -4.3 & & \\
$55+$ & 72 & 92.2 & -20.2 & & \\
Total & 508 & & & & \\
\hline
\end{tabular}

Source: own processing

a. 0 cells $(0.0 \%)$ have expected frequencies less than 5 . The minimum expected cell frequency is 229.6.

b. 0 cells $(0.0 \%)$ have expected frequencies less than 5. The minimum expected cell frequency is 25.3. 
Based on the results of the One Sample Chi-square test, it can be claimed that the research sample is representative only in gender breakdown (asymp. sig. > 0.05). However, the sample is not representative by age (asymp. sig. < 0.05). From a deeper analysis, we found that the reason for the unrepresentativeness of the sample in terms of age is the high number of respondents under 24 years and, conversely, the low number of respondents older than 55 years. We assume that this could be due to the distribution of questionnaires using social networks. Anyhow, it's a limitation of our research, and the claims we make will only apply to our research sample, not to the entire population. We further analysed the results of the questionnaire survey using descriptive statistics. Since the examined variables were mostly nominal, we used the Chi-Square Test of Independence with Cramer's V to determine the dependencies between them.

\section{Results and discussion}

First, we were interested in whether the respondents are even interested in the issue of leadership. Less than a third of respondents $(31.89 \%)$ are really interested in this issue, only $28.35 \%$ have even read or studied professional literature on the topic. It can therefore be said that the majority of respondents are not professionally involved in management studies, which we evaluate positively, because they are not largely influenced by theoretical knowledge. Subsequently, we were interested in whether the respondents consider leadership to be important for the success of the entire company. More than three quarters $(77.95 \%)$ of the respondents answered positively, $12.01 \%$ negatively and $10.04 \%$ had no opinion on this issue. In Table 4 , we see that there is a strong relationship between interest in leadership and the perceptions of its importance. This means that people who are interested in the issue of leadership understand its importance more often than those who are not interested in this issue at all.

Table 4 Interest in leadership and the understanding of its importance

\begin{tabular}{|c|c|c|c|c|c|}
\hline & & \multicolumn{3}{|c|}{ Importance of leadership } & \multirow[t]{2}{*}{ Total } \\
\hline & & Important & No opinion & Not important & \\
\hline \multirow{3}{*}{\multicolumn{2}{|c|}{$\begin{array}{l}\text { Interest in } \\
\text { leadership } \\
\text { Total }\end{array}$}} & 161 & 0 & 1 & 162 \\
\hline & & 235 & 51 & 60 & 346 \\
\hline & & 396 & 51 & 61 & 508 \\
\hline \multicolumn{2}{|c|}{ Chi-Square Tests } & \multicolumn{2}{|c|}{ Value } & df & Asymp. Sig. (2-sided) \\
\hline \multirow{4}{*}{\multicolumn{2}{|c|}{$\begin{array}{l}\text { Pearson Chi-Square } \\
\text { Likelihood Ratio } \\
\text { Linear-by-Linear Association } \\
\text { N of Valid Cases }\end{array}$}} & \multicolumn{2}{|c|}{$63.591 a$} & 2 & 0.000 \\
\hline & & \multicolumn{2}{|c|}{90.784} & 2 & 0.000 \\
\hline & & \multicolumn{2}{|c|}{55.022} & 1 & 0.000 \\
\hline & & & 08 & & \\
\hline \multicolumn{2}{|c|}{ Symmetric Measures } & \multicolumn{2}{|c|}{ Value } & \multicolumn{2}{|c|}{ Approx. Sig. } \\
\hline \multirow{3}{*}{\multicolumn{2}{|c|}{$\begin{array}{l}\text { Nominal by } \\
\text { Nominal Cramer's V } \\
\text { N of Valid Cases }\end{array}$}} & \multicolumn{2}{|c|}{0.354} & \multicolumn{2}{|r|}{0.000} \\
\hline & & \multicolumn{2}{|c|}{0.354} & \multicolumn{2}{|r|}{0.000} \\
\hline & & \multicolumn{2}{|c|}{508} & & \\
\hline
\end{tabular}

a. 0 cells $(0.0 \%)$ have expected count less than 5. The minimum expected count is 16.26 .

Source: own processing 
We were also interested in whether the respondents consider their immediate superiors to be a leader. Only $19.49 \%$ of respondents do not rate their bosses to be leaders, $37.80 \%$ of respondents thinks the opposite and $42.72 \%$ of respondents consider their superior to be a leader only in certain situations. When looking for an answer to the first research question, we claim that $80.51 \%$ of Slovak employees at least sometimes consider their superior as a leader. We consider this share to be high enough; therefore, the response to RQ1 is affirmative. This question was followed by another one, in which we found out why they responded in one way or another, according to which they judge what reason they have to claim that their superior is or is not a leader, or why only occasionally. The most common reasons for the occasional perception of the superior as a leader were the claims that their superior is very moody, or that he is significantly affected by the operation of production, the operation. Another frequent justification was the fact that the superior lacked determination. They claimed that the superiors are either afraid to show up or that their decisions are greatly controlled and influenced by their own superiors. A recurring reason was also that, according to the respondents, their superior does not have natural authority or is losing it. According to them, authority is important. This is followed by other answers in which the respondents state that they have a very friendly relationship with their superiors and therefore do not take them seriously, even though they know what they can and cannot afford, given that the person in question is higher on the corporate ladder. Thanks to these answers, too, we see that the authority of the superior is disappearing because of their friendly relationship. Less recurring reasons were that the superior lacked the necessary knowledge, was not interested in subordinates, did not have time for them, did not communicate with them, had high demands on them, did not know his competencies, did not have a sufficient overview of the company, was not an integrated member of a team. Some respondents associated leadership with leadership style. Some are hampered by the benevolence of their superior and think that it is holding them back to be a true leader, and others, on the contrary, demand more freedom from their direct superior. Here, too, we perceive the power of respondents' subjectivity.

Those who claimed that their superior was clearly the leader accounted for $37.80 \%$. They, too, had the opportunity to justify why they think so. Some mentioned qualities, such as receptivity, empathy, representativeness, helpfulness, fairness, directness, responsibility, intelligence, foresight, self-confidence, dexterity, communicativeness, decency and honesty towards subordinates and clients. Other respondents listed what their manager was doing specifically for them or what their relationship was like. They consider their managers leaders because they help them move forward in the company, and they areinterested in their development. They always support them, constantly motivate and encourage them, they do not need to be afraid when they turn to them with any matter or problem. When something goes wrong, managers encourage them, and they are friends with a certain authority. According to the respondents, authority and respect that radiate from their superiors are another important element. Some even use the term natural authority themselves. Many repetitive and similar responses concerned how their superior manages and coordinates their work and how tasks are delegated.. They refer to it as good organizational and managerial skills. They say that the manager gives clear commands, clearly assigns individual tasks, which are always explained. The manager knows exactly what he or she wants, knows how to divide, organize and synchronize work well, and is not afraid to become part of the team, to work and participate in tasks and goals. According to them, it is also important that their superior has an 
overview of everything, and the necessary knowledge and information about the operation of the company. Goof managers can provide everything they need to ensure and that they solve problems with a cool head. They are good role models and a role model for other colleagues, for example, because they work hard on themselves, that they constantly learn and like to face challenges. However, there were also justifications, such as "because he is the boss, because he has a higher position, because he is a superior, because they have to obey and respect him." In these responses we clearly see that the given respondents have a wrong view of leadership or they do not know what the term involves. Respondents who do not perceive their superior as a leader most often gave as a reasons that he does not know how to work and communicate with people, does not have natural authority and sufficient respect, cannot make order in the workplace. He also hinders them that he does not have sufficient education, is not competent, that he lacks information about the company, about the work of individual subordinates and therefore does not understand them. Respondents often refer to their managers' behaviour, that they use their power more to prove superiority and not to the benefit of the company. They also say that they have a huge ego, that they lack empathy and managerial skills, that they do not know how to work with people, that they are not independent and creative, that they do not develop, progress both themselves and their subordinates. Some replied that they were too friendly to others. On the contrary, others perceive authoritarianism as an inappropriate trait for a leader. This way we answered the research questions RQ2 and RQ3.

Subsequently, we investigated whether the respondents are thinking or have been thinking about changing jobs, which would, of course, increase employee turnover in the company. Almost a half $(45.08 \%)$ of respondents thought about changing jobs often, $37.99 \%$ of respondents sometimes and only $16.93 \%$ of respondents did not thought about it at all. We used the Chi-Square Test of Independence with Cramer's V to calculate the relationship between a supervisor's leadership qualities and job change thoughts of the employees. The results are shown in Table 5.

\section{Table 5 Perception of the boss as a leader and thoughts about changing jobs}

\begin{tabular}{|c|c|c|c|c|c|}
\hline & & \multicolumn{3}{|c|}{ Thoughts about changing job } & \multirow{2}{*}{ Total } \\
\hline & & No & Sometimes & Often & \\
\hline \multirow{3}{*}{$\begin{array}{c}\text { Boss is a } \\
\text { leader }\end{array}$} & Yes & 173 & 15 & 4 & 192 \\
\hline & Sometimes & 41 & 166 & 10 & 217 \\
\hline & No & 15 & 12 & 72 & 99 \\
\hline Total & 229 & 193 & 86 & 508 & \\
\hline \multicolumn{3}{|c|}{ Chi-Square Tests } & Value & df & Asymp. Sig. (2-sided) \\
\hline \multicolumn{3}{|c|}{ Pearson Chi-Square } & $513.703 a$ & 4 & 0.000 \\
\hline \multicolumn{3}{|c|}{ Likelihood Ratio } & 460.225 & 4 & 0.000 \\
\hline \multicolumn{3}{|c|}{ Linear-by-Linear Association } & 268.936 & 1 & 0.000 \\
\hline \multicolumn{3}{|c|}{$\mathrm{N}$ of Valid Cases } & 508 & & \\
\hline \multicolumn{3}{|c|}{ Symmetric Measures } & Value & \multicolumn{2}{|r|}{ Approx. Sig. } \\
\hline \multicolumn{3}{|c|}{ Nominal by Nominal } & $\begin{array}{c}\text { Phi } \\
\text { Cramer's V }\end{array}$ & \multicolumn{2}{|r|}{$\begin{array}{l}1.006 \\
0.711\end{array}$} \\
\hline \multicolumn{3}{|c|}{$\mathrm{N}$ of Valid Cases } & 508 & & \\
\hline
\end{tabular}

a. 0 cells $(0.0 \%)$ have expected count less than 5. The minimum expected count is 16.76.

Source: own processing 
Based on the results of the Chi-Square test, we reject the assumption that the variables examined are independent. Cramers $\mathrm{V}$ shows that there is a strong relationship. We can therefore say that Slovak employees often consider changing jobs because they do not consider their superior as a leader. Thus, we answered the research question RQ4. At the same time, the need to strengthen leadership was confirmed. This finding confirms the views of Armstrong (2007), referring to research by British Industrial Relations Services, that leadership is the most significant impact on employee commitment and satisfaction. Prior studies have demonstrated that authentic leadership contributes to the retention of employees by reducing their emotional exhaustion (Laschinger, Fida, 2014). Tumilaar (2015) adds that leadership, in addition to stabilizing employees, also has a significant impact on their performance. According to Azanz et al. (2015), authentic leaders may be able to influence employee turnover intention by increasing their work engagement, which might be achieved by acting as role models and transmitting their commitment and connection to the work to employees. On the other hand, the perception of leadership is very individual and can be influenced by many factors, such as the personal attitudes of employees, their previous experience, cultural specifics or the size of the company. Oh and Oh (2017) revealed that leadership interacted with organizational size to influence employees' levels of affective commitment, indicating that authentic leadership behaviours are more effective in improving employee commitment in smaller organizations. Our research was therefore focused on the conditions of Slovak companies with regard to all domestic specifics.

\section{Conclusion}

In every company, employee relations are very important. But if we want to develop leadership, these relationships must take on a different dimension. To expand them by taking an interest in the development of others, helping them to progress, constantly motivating and encouraging them, being willing to help them, standing by them in every situation, being a so-called committed team member. In addition to all work responsibilities, it is of course difficult to be available to others at all times. However, the gradual demonstration of a such interest in others, and not just the pursuit of one's personal interests, will have a positive effect not only on strengthening the quality of employment relationships but also on the quality of leadership.

Thanks to the analysis of the results of the questionnaire survey, we found out how the respondents are interested in leadership, what their awareness in this area is. Furthermore, we obtained an insight into the current state of leadership, which is represented by people in superior positions and what impact it has on employees and their overall satisfaction. We also came to the conclusion that there are certain specific characteristics and actions that are desirable and undesirable for leadership. Authority is a very important attribute of leadership. However, it is not the authority that comes with the position but natural authority. That's why people in leadership positions should work on building it. The natural respect and authority that is created, because subordinates want and do not have to, is very difficult to gain. By striving to be a good role model for others, whether through qualities, behaviors, or abilities, or through good and constructive influence, it is possible to gain employee devotion gradually. Intensified leadership can also be achieved through improved leadership skills. For example, by giving clear commands, clearly identifying tasks, illustrating and explaining a given task, good coordination of own work and the work of others, 
or participation in achieving set goals. Another proposal to support the creation of leadership is the strengthening and acquisition of individual characteristics that are most considered to be signs of leadership. These are, for example, receptivity, empathy, representativeness, helpfulness, fairness, directness, responsibility, intelligence, foresight, informativeness, self-confidence, dexterity, communicativeness, decency and honesty. Conversely, to eliminate moodiness, independence, hostility, disinterest, noninvolvement, unwillingness to help and educate others and oneself, and especially to eliminate the use of power to prove superiority.

Leadership is a complex topic and it is difficult to identify clear proposals or steps to encourage it in business practice, because each employee is different. Everyone expects and wants something different from the leader, something different from the leader according to their job position. No proposal will be $100 \%$ correct and usable for everyone equally, but a gradual effort to implement them will certainly strengthen the level of leadership.

The topic of leadership is very interesting but also challenging. It can be explored from many perspectives, in scope and to different depths. We addressed it through many respondents from different companies and with different leaders. Although we have also suggested ways to strengthen its level, a different dimension should certainly be addressed to individual companies separately. Further research should examine the context in them, gather as many opinions as possible on one researched object, eliminate the subjectivity of the employees involved and thus come up with individual and almost completely accurate proposals to improve leadership in specific companies.

\section{Bibliography}

1. Armstrong, M. (2007). Řízení lidských zdrojů. [preklad Josef Koubek] Praha : Grada Publishing, 2007. 800 p.

2. Azanza, G., Moriano, J.A., Molero, F. \& Lévy Mangin, J.P. (2015). The effects of authentic leadership on turnover intention, Leadership \& Organization Development Journal, 36(8), pp. 955-971. https:/ / doi.org/10.1108/LODJ-03-20140056

3. Bass, B. M., \& Bass, R. (2009). Bass Handbook of Leadership: Theory, Research, and Managerial Applications (4th ed.). New York: Free Press. 4730 p.

4. Blažek, L. (2014). Management: organizování, rozhodování, ovlivňování. Praha : Grada, 2014. 211 p.

5. Cangemi, J. P., Burga, B., Lazarus, H., Miller, R.L. \& Fitzgerald, J. (2008). The real work of the leader: a focus on the human side of the equation. Journal of Management Development, 27(10), pp. 1026-1036. https:/ / doi.org/10.1108/02621710810916286.

6. Dirani, K., Abadi M., Alizadeh, A., Barhate, B., Garza, R., Gunasekara, N., Ibrahim, G. \& Majzun, Z. (2020) Leadership competencies and the essential role of human resource development in times of crisis: a response to Covid-19 pandemic. Human Resource Development International, 23(4), pp. 380-394, https://doi.org/10.1080 /13678868.2020.1780078

7. Drucker, P. (1996). Your Leadership Is Unique. Good News: There Is No One Leadership Personality. Christianity Today International/Leadership Journal, Vol. 17, pp. 54-55.

8. Goleman D. (1998). What makes a leader? Harvard business review, 76(6), pp. 93-102. 
9. Gozora, V. (2005). Podnikový manažment. Nitra : Slovenská pol'nohospodárska univerzita. $190 \mathrm{p}$.

10. Harris, A. Leithwood, K., Day, C.,Sammons, P. \& Hopkins, D. (2007). Distributed leadership and organizational change: Reviewing the evidence. Journal of Educational Change, 8(4), pp. 337-347. https:/ / doi.org/10.1007/s10833-007-9048-4.

11. Kassay, Š. (2013). Riadenie. Prvá čast', Vodcovia a manažéri. Bratislava : Veda. $181 \mathrm{p}$.

12. Laschinger, H. K. S. \& Fida, R. (2014). A time-lagged analysis of the effect of authentic leadership on workplace bullying, burnout, and occupational turnover intentions. European Journal of Work and Organizational Psychology, 23(5), pp. 739-753.

13. Lunenburg, F. (2011). Leadership versus Management: A Key Distinction - At Least in Theory. [online] International journal of management, business, and administration. 14(1). [cit. 2020-08-17]. Available on the internet: <http:// www.nationalforum.com/Electronic\%20Journal\% 20Volumes/Lunenburg, \%20 Fred \%20C. \%20Leadership\%20versus \%20Management \%20IJMBA \%20V14\%20 N1\%202011.pdf>

14. Nanjundeswaraswamy T. S., \& and Swamy D. R. (2014). Leadership styles. Advances In Management, 7(2), pp. 57-62.

15. Oh, J. \& Oh, S. (2017). Authentic leadership and turnover intention: does organizational size matter? Leadership \& Organization Development Journal, 38(7), pp. 912-926. https:/ / doi.org/10.1108/LODJ-08-2016-0209

16. Rasool, H.F., Arfeen, I.U., Mothi, W. \& Aslam, U. (2015). Leadership styles and its impact on employee's performance in health sector of Pakistan. City University Research Journal, 5(1), 97-109.

17. Sedlák, M. \& Líšková, C. (2015). Manažment. Bratislava : Wolters Kluwer. 387 p.

18. Statistical office of the Slovak Republic (2021). Databases [online]. [cit. 2020-1018] Available on the internet: <http://statdat.statistics.sk/cognosext/cgi-bin/ cognos.cgi?b_action $=$ cognos Viewer\&ui.action=run\&ui.object $=$ storeID $(\% 22 \mathrm{i} 42 \mathrm{~A}$ 8A014A687495596DC929810349606\%22)\&ui.name=Employed \%20by \%20age \% 20 \%5bpr3115qr\%5d\&run.outputFormat=\&run.prompt=true\&cv.header=false\&ui. backURL=\%2fcognosext $\% 2$ fcps $4 \% 2$ fportlets $\% 2$ fcommon $\% 2$ fclose.html $>$

19. Steigauf, S. (2011). Vůdcovství: aneb Co vás na Harvardu nenaučí. Praha : Grada Publishing. 368 p.

20. Sutton, R. I. (2010). Dobrý šéf, zlý šéf : ako sa stat' najlepším a poučit' sa od najhorších. [preklad Michal Zidor] Bratislava : Eastone Books. 193 p.

21. Theodoulides, L. (2018). Reflective leadership: a process-relational approach to enhance organizational change. Banská Bystrica: Belianum : Ekonomická fakulta Univerzity Mateja Bela v Banskej Bystrici. 155 p.

22. Thomasová, E. (2000). Moderné trendy v organizačnej štruktúre podnikov. Bratislava : Ekonomická univerzita. 121 p.

23. Tumilaar, B. R. (2015). The effect of discipline, leadership, and motivation on employee performance at BPJS Ketenagakerjaan SULUT. Jurnal Emba: Jurnal Riset Ekonomi, Manajemen, Bisnis dan Akuntansi, 3(2). pp. 758-883. https://doi. org/10.35794/emba.v3i2.8901 


\section{Correspondence address:}

Mgr. Ing. Lukáš Smerek, PhD., Department of Corporate Economics and Management, Faculty of Economics, Matej Bel University in Banská Bystrica, Tajovského 10, 97590 Banská Bystrica, email: lukas.smerek@umb.sk

Ing. Monika Šurinčíková, Department of Corporate Economics and Management, Faculty of Economics, Matej Bel University in Banská Bystrica, Tajovského 10, 97590 Banská Bystrica, email: monicka.surincikova@gmail.com 